\title{
Det åndelige klima i Sverige efter mordet på Gustaf III
}

af docent, fil.dr. Gunnar Syréhn, Institut for nordisk filologi, Københavns Universitet

Der findes en scene i Lars Forssells teaterstykke Galenpannan (Galfrans), som har fascineret mig lige siden jeg stødte på den første gang. Personen, der kaldes Galenpannan, men som egentlig forestiller Sveriges afsatte konge, Gustaf IV Adolf, sidder som landflygtig nede i Sankt Gallen og drømmer om at få lov at dø på samme måde som faderen Gustaf III, nemlig ved et pistolskud. Dette bliver ham dog ikke forundt; han dør på scenen ligesom i virkeligheden af et slagtilfælde, men lige før han falder om, råber han teatralsk og triumferende: "Der kom skuddet!"

Dermed er cirklen sluttet; mordet på Gustaf III i 1792 blev, som vi ved, slutningen på en æra i svensk historie og naturligvis samtidig begyndelsen på en ny tid, og hvis det er sandt, at historien er kongernes, som Erik Gustaf Geijer opfattede det, så afsluttedes denne epoke med afsættelsen af Gustav IV Adolf i 1809. Mellem de poler som udgøres af Gustaf IIIs død og revolutionen i 1809 vil også min fremstilling hovedsageligt bevæge sig.

Som vi ved, nærede Bellman en gensidig kærlighed til Gustaf III, og hans hyldester kan synes rørende i deres uskyldige underdanighed. Fredmans sang nr 64 "Fjäriln vingad syns på Haga", afsluttes med den tanke, at den, som rammes af Gustafs blide blik, begynder at græde af taknemmelighed, og at den sørgende bliver glad bare monarken ser på ham. ${ }^{2}$

Eller tag "Gustafs skål", som skjalden skrev for at hylde kongen ved den ublodige revolution i 1772, og hvor han lovpriser Gustaf III som "Den bedste konge, som Norden ejer", en som ikke bare er "God og glad", men tillige retfærdig og udrustet med evnen til at gennemskue dårskab. ${ }^{3}$ 
"Gustafs skål” har et søsterdigt som begynder med ordene "Således lyser din krone nu, Kong Gustaf, dobbelt dyrebar" ${ }^{4}$ I et andet teaterstykke af Lars Forssell, Haren og Musvågen, har skælmen Guntlack fået fat i manuskriptet til denne sang og bebrejder Bellman hans devote hyldester til kongen. Bellman forsvarer sig med et spagt og stammende "Man m-må have brød på bordet". ${ }^{5}$ Dette kan vel siges at være en rimelig grund, men det er også sandt, at for Bellman kunne Gustaf IIIs genialitet ikke drages i tvivl.

Derfor ramte mordet på kongen ham naturligvis hårdt. Gustaf III døde som han havde levet, teatralskt. Han påtog sig sit livs sidste rolle og kreerede den pompøst. Fuld af skrot fra Ankerströms pistol befalede kongen: "Arrester [gerningsmanden] men gør ham ikke ondt". ${ }^{6}$ Udråbet kan jo være dikteret af et ønske om, at denne senere skulle forråde eventuelle medskyldige, ${ }^{7}$ men kom sikkert også til at indgå i billedet af den milde landsfader, som til og med tilgav sin morder.

Tidligere havde de mest radikale ment, at kongen havde fortjent en Cæasars skæbne, omend få havde villet påtage sig Brutus' rolle, men kongens optræden og afsky overfor forbrydelsen gav ham nu folkets sympati. Ligesom de forgængere i embedet, som Gustaf som librettist selv havde stillet på operascenen, kom han nu i fokus, båret oppe af folkets kærlighed. ${ }^{8} \mathrm{Og}$ den niddingsdåd, han blev ramt af, skete ovenikøbet i samme operahus hvor man tidligere opførte hans egne teaterstykker.

Taknemmelighedens tårer, som synet af monarken fremkaldte på Haga, udskiftedes nu med sorgens. Bellman indfandt sig hos sin ungdomsven Erik Palmstedt, hvor det nu "vekslede mellem tårer og udråb af den dybeste bedrøvelse", som det hedder i en optegnelse af sønnen Carl Palmstedt. 9 Efter at kongen er afgået ved døden som følge af skuddet, skriver Bellman en sørgesang, hvori han forestiller sig, at det skete ikke er dødens fejl, men at en "arrig bandit" bærer skylden. Døden selv går sørgende og forundret frem og tilbage, "Bærer sit timeglas, stum og berørt". ${ }^{10}$ Bellman skrev også et mindedigt på 33 aleksandriner, hvor det i sidste vers hedder: "Ej noget geni fødes, som ej med bortvendt øje / Begræder Gustafs død ved lyren, bedrøvet og trist". 11

Andres sorg over kongens død var ikke mindre, selv om den så småt naturligt nok aftog og kunne give anledning til situationer, hvor grænsen mellem oprigtighed og parodi blev udflydende. Således kulminerede bedrøvelsen, da statuen af Gustaf 


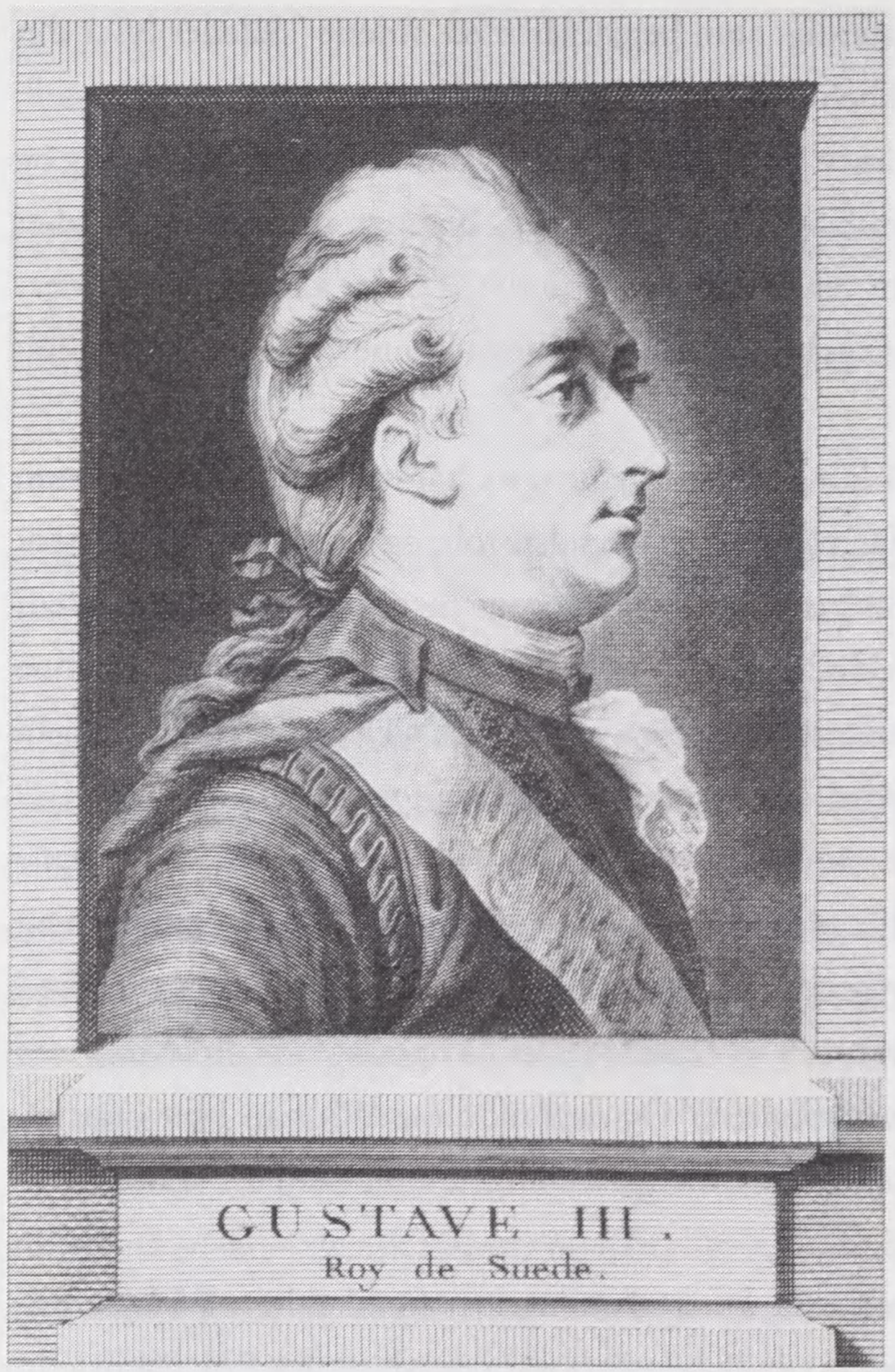

Gustav III, svensk konge 1771-1792.

Han havde som mæcen stor betydning for Sveriges litteratur og kunst, ligesom han selv skrev flere dramaer. Han satte sin ånds præg på sin tidsalder; oprettede efter fransk mønster "Svenska Akademien" i 1786.

III som Apollon afsløredes på Skeppsbroen i Stockholm i 1808 og dens skaber Sergel sidenhen holdt en fest for gamle gustavianere. Der udbragte han kongens skål med ordene: "Det billede jeg har lavet af ham er dårligt, men vi har hans billede i vore hjerter”. Sekretæren i Det svenske Akademi, Rosenstein, var da, rørt af både talen og stærke drikke, gået under bordet, og da han blev bebrejdet at han ikke deltog i skålen, forsvarede han sig med ordene: "Den skål drikker jeg altid knæ-lende!"12

Men tilbage til 1792. Den gustavianske musikdramatik som kongen hægede så meget om, når ikke sin kulmination i en opera men derimod $\mathrm{i}$ hans egen begravelse. Den blev et storslået skuespil i form af en Begravelseskantate for Gustaf III med musik af Joseph Martin Kraus og libretto af Carl Gustaf af Leopold, to af epokens ypperste kunstnere. 
Riddarholm-

kirken i Stock-

holm.

Gravkirke for svenske konger og fremragende svenske mænd siden 1600tallet.Kort- og Billedafdelingen

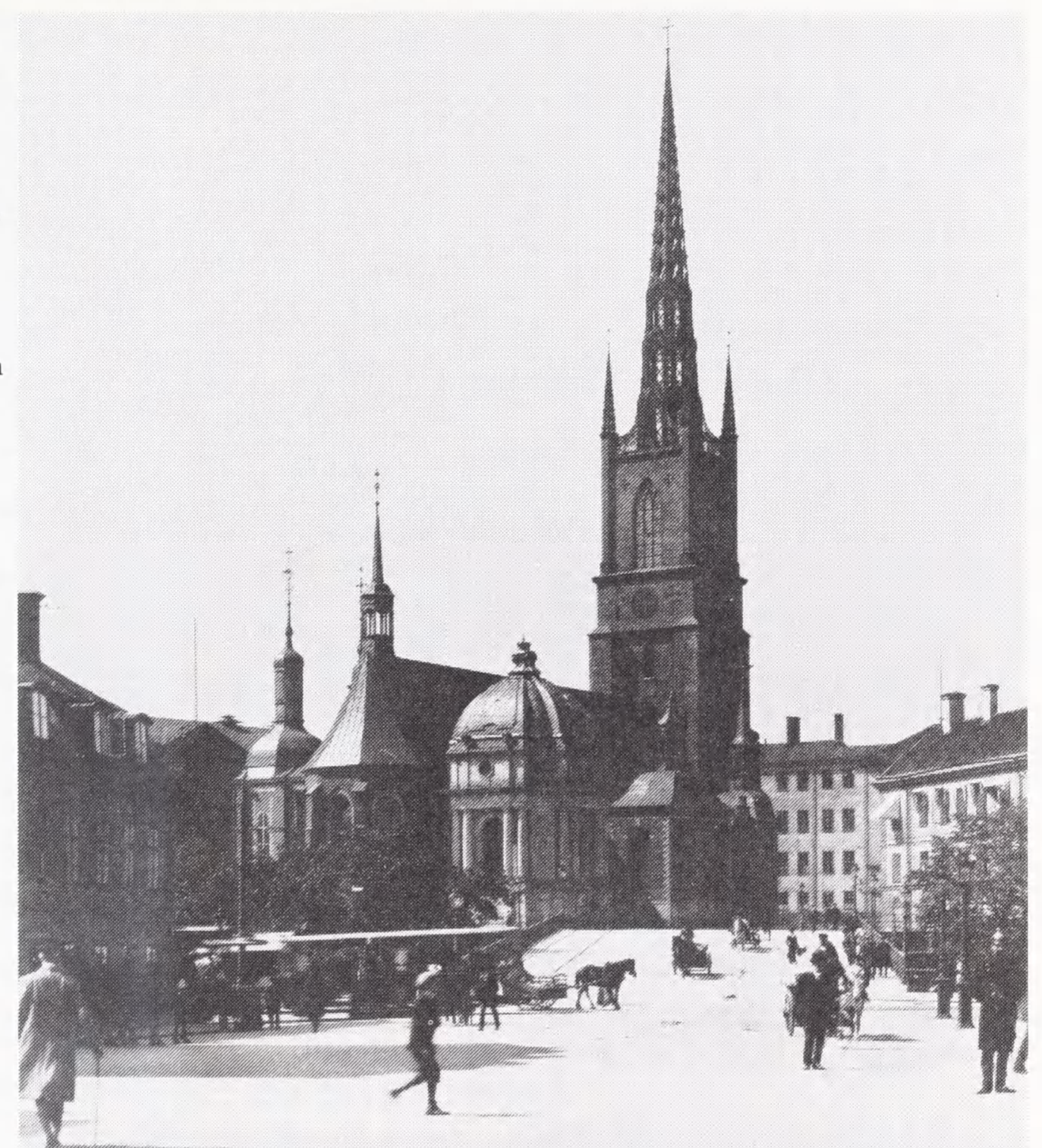

I anledning af dagen var Riddarholmskirken blevet forvandlet til et storslået teaterrum med dekoration af Louis Jean Desprez, manden om hvem Gustaf III en gang siges at have sagt: "Vi er kun to i Sverige som ejer fantasi: Desprez og jeg!"13

"Slå jer for brystet, og riv itu jeres / klæder; / ak, ak, Gustaf er ej mere" hedder det i Leopolds tekst om "Sveriges helt, konge og fader" ${ }^{14} \mathrm{Og}$ musikken er ikke mindre pompøs. I tilslutning til Glucks idéer tager koret aktiv del i handlingen, og træder frem for folket som udsynger dets vrede over mordet på den elskede konge. En smagsprøve på kormusikken findes iøvrigt på en CD med svensk 1700talsmusik. ${ }^{15}$

Myrdet på en maskerade i sit eget operahus, får Gustaf sin sidste rolle som hovedperson til sin egen begravelse i et til en operascene forvandlet kirkerum, hvor 


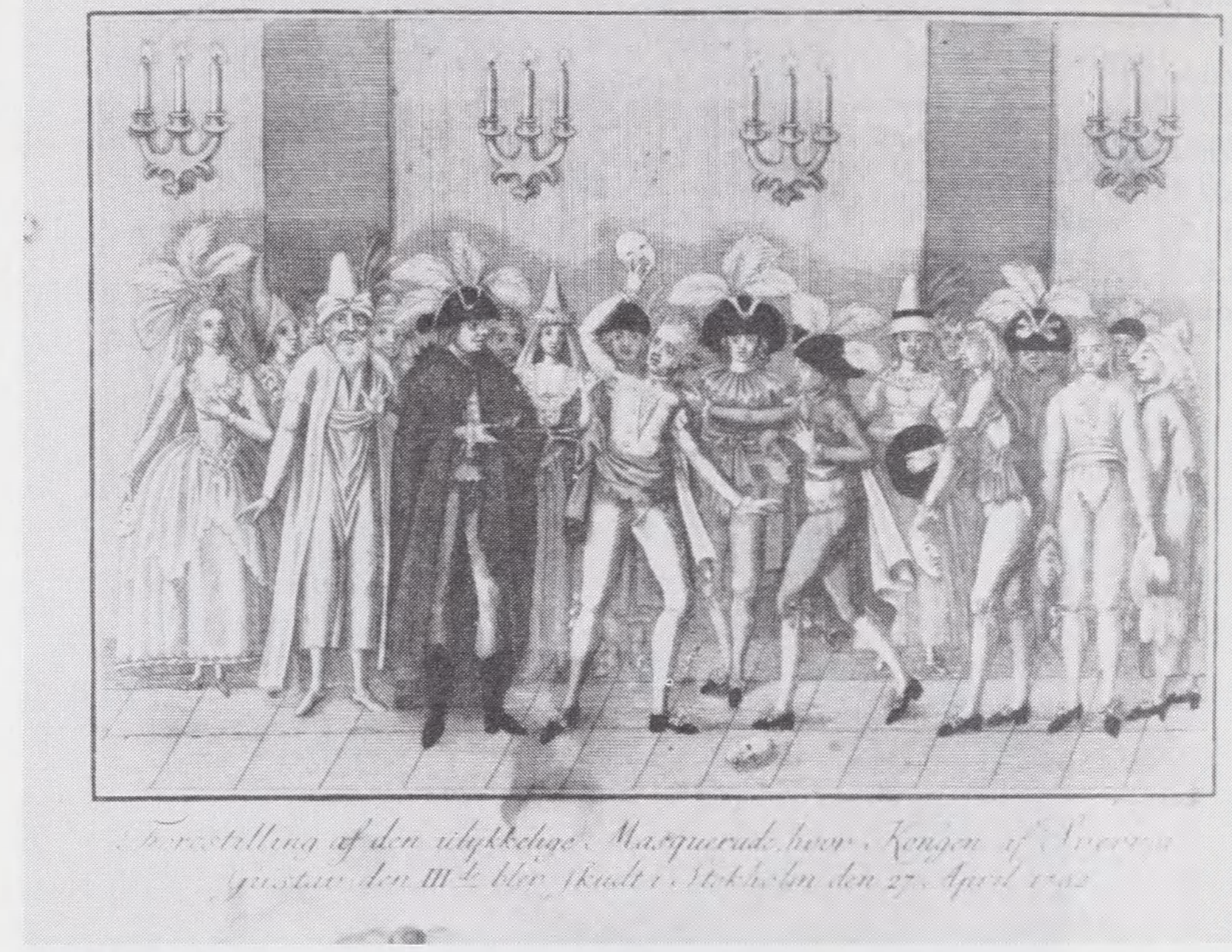

"Forestilling af den ulykkelige Masquerade, hvor Kongen af Sverrig Gustav den IIIde blev Skudt i Stockholm den 27. April 1792. "Kort- og Billedafdelingen.

han til slut bæres ind i en del af dekorationen, nemlig en vældig gravhøj som placeres i centrum for tilskuernes opmærksomhed. Kan man tænke sig en bedre slutning på en teaterkonges bane?16

De hyldester, som den i sin levetid omstridte Gustaf III fik efter sin død, minder ikke så lidt om det der skete efter mordet på Olof Palme. Også denne var både elsket og hadet, men det afskyelige i gerningen skabte i en periode en fælles sorg, hvor fă, om nogen overhovedet, tog ordet for at kritisere, hvad statsministeren havde arbejdet for mens han levede, og hvor også tidligere fjender hyldede ham i den periode, det første chok varede.

Skuddet på Operaen og skuddet på Sveavägen havde også det tilfælles, at de skabte forvirring og frygt. Man spurgte sig selv, hvad der nu skulle ske, hvem eller hvilke der skulle rammes herefter og hvilke forandringer, der stod for døren.

Under den første forvirring efter attentatet på Gustaf III og inden man vidste, hvor stort komplottet var, iværksattes en mængde undtagelsesforanstaltninger: Man 
måtte ikke forlade Stockholm, ikke færdes ude om natten uden lygte, ikke opbevare krudt hjemme, og der spredtes et rygte om, at der ved morderens på galgen fastsømmede hånd fandtes en seddel med ordene "Velsignet være denne hånd, som har frelst Svea land". ${ }^{17}$

Et andet rygte gjorde gældende, at selv damer af højere klasse havde kjolelommerne fulde af revolutionære blade. ${ }^{18} \mathrm{Og}$ her har vi et af genstandene for menneskenes frygt: revolutionen. Myndighederne havde mistanke om, at attentatet kunne være frugten af en jakobinsk sammensværgelse, hvilket ikke er overraskende. Da Bastillen faldt, havde dette vakt begejstring i Sverige. Johan Henric Kellgren, den gustavianske litteraturs fører, "græd som et barn, en mand" da han hørte om det, og til og med Bellman påstås at have sunget om egalité på vejen hjem fra et ordensmøde. ${ }^{19}$

For en tid spredte der sig nu en usikkerhed over landet, en usikkerhed som ind imellem steg til skræk, og ikke før Reuterholm overtog befalingen over Sverige i juli 1792 blev det midlertidigt klart, hvem der behøvede være bange i fremtiden og hvem der kunne slippe for det.

Da Gustaf III døde efterlod han sig en søn, den kommende Gustaf IV Adolf, men mens denne endnu ikke var myndig, skulle Gustafs bror, Carl, være regent. Hertug Carl er blevet beskrevet som "en af de svageste karakterer som nogensinde er tynget af jordisk højhed," 20 og som for at fuldende tragikomikken, blev det snart Carls tur til at blive regeret af kammerherre Gustaf Adolf Reuterholm, "en anestolt, småtskåren og selvoptagen nar, ført til magten af en regent som i naragtighed ikke lod ham noget efter", en som "manglede evnen til at tænke klart", for at citere en anden karakteristik. ${ }^{21}$ Læg dertil at både Gustaf IV Adolf og formynderregimet under Reuterholm var stærkt kulturfjendtligt, og vi vil forstå, at det åndelige klima i Sverige stod over for nogle svære år.

Reuterholm frygtede en folkelig revolution som den i Frankrig, men han var også bange for, at de gamle gustavianere skulle få indflydelse på den nye konge. Han anså det derfor som sin første store opgave at eliminere denne risiko. I Svenska siare och skalder beretter Atterbom således, at en stor del af oplaget af Bellmans sørgedigt "Konungens DÖD och MINNE på Klago-Dagen den 6 Junii 1792" blev inddraget eller makuleret, 22 ved hoffet spilledes Gustaf IIIs begravelsesmusik som spøgefuld underholdning, alle der åbent viste sorg blev hånet, og de kunstnere, som tidligere støttedes, følte sig nu højst uvelkomne på slottet. ${ }^{23}$ "At elske og savne Gustaf 


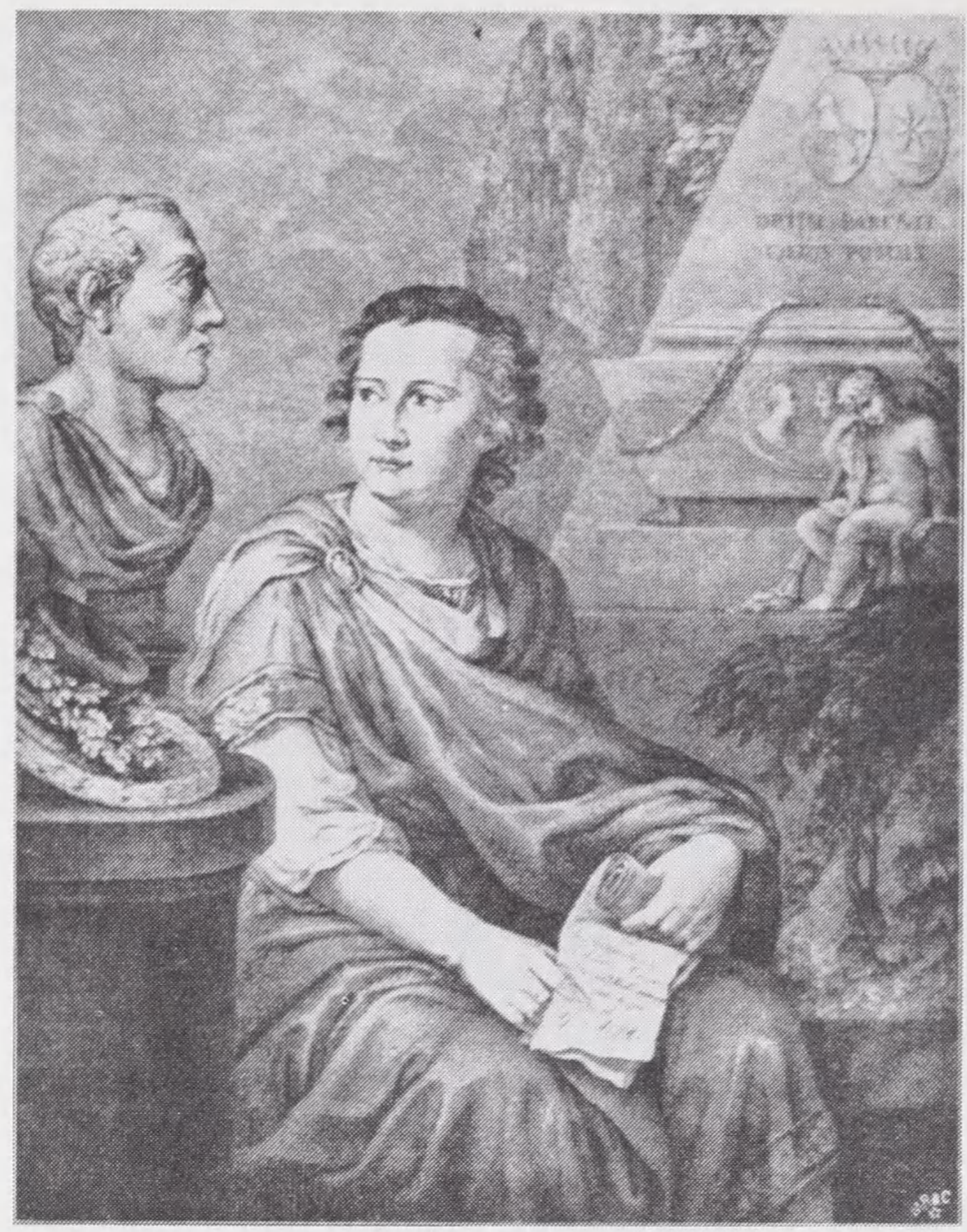

Gustav Adolf v. Reuterholm, 1756-1813. "En anestolt, småtskåren og selvoptagen nar, ført til magten af en regent som i naragtighed ikke lod ham noget efter"

(Bengt Åhlén, Ord mot ordningen. 1986)

Reuterholm var i opposition til Gustav III, men blev efter hans død den egentligt ledende i den svenske regering under formynderstyret. Da Gustav IV Adolf selv overtog regeringsmagten i 1796, blev han forvist fra Stockholm.

den Tredie var en meget nem måde at gøre sig upopulær på, om ikke hos den nye regent, så hos hans regerende vizir" siger Atterbom. ${ }^{24}$ Ikke mærkeligt hvis digterne forstummede.

Det gjorde de dog ikke allesammen. Tværtimod finder jeg det bemærkelsesværdigt, at så meget trods alt kunne blomstre i Sverige under de strenge år frem til 1809. Ved mordet på Gustaf III havde Bellman kun tre år tilbage at leve i, men han skrev netop i den periode nogle af sine mærkeligste værker. For at tage det mindst mærkelige først, så fortsatte han med at hylde kongehuset: "I Gustaf Adolfs navn nyder vort samfund beskyttelse / Et navn som rummer folkets glæde i sin genklang /Således dyrket i vort Norden, som det i sekler lyser / og os til minde om to kronede heltes dyd", læser han op i egenskab af Augusti Ordenens talsmand den 19. august 1794, mærket af den sygdom som snart skulle sætte ham på Charons færge med den opfordring, han selv kommer med i sidste vers: “Og, under overfarten, besyng højt regentens ære!".25 
Det mærkeligste er dog, at Bellmans bedste prosaværk blev til under de besværlige sidste år, bl.a. hans mest vellykkede teaterstykke Mandtalsskrivningen, som ganske vist opførtes i en ældre version allerede mens Gustaf III levede, men som fik sin definitive skikkelse i $1794 .{ }^{26} \mathrm{Og}$ så naturligvis det som normalt kaldes Levnedsbeskrivelsen, men som Bellman selv gav den ironiske hovedoverskrift "Det kongelige Slot den 8. Maj 1794"27, fordi han sad fanget i slottets hovedvagtfløj.

Der er tale om et fragment, og uden at prale, kunne man vel tænke sig, at en fuldbyrdet beskrivelse skulle kunne måle sig med Johannes Ewalds Levnet og Meninger. ${ }^{28}$ Bellman som lysende prosaforfatter skal ikke helt stå i skyggen af hans poesi.

Selv om de styrendes modtagelse af Bellmans hyldester til Gustaf III var kølig, fandt man ingen anledning til at skride ind overfor Bellmans person eller hans skrifter; hverken æstetisk eller politisk var han nogen autoritet for samtiden, og altså ikke en person som man var for eller imod. Kellgrens frifindelse i fortalen til Fredmans epistlar gjaldt fortsat, og den moralske fordømmelse af hans digte kom først langt senere.

Der er en historie om Bellman, som siger en del om hans forhold til det nye styre. En af Reuterholms spioner havde været i en klub for dér at finde ud af om der skete noget farligt, og rapporterede bagefter at alt var roligt. Der "tales ikke om noget, men Bellman sidder der hele dagen og synger viser for herrerne". ${ }^{29}$ Bellman var ikke farlig.

Andre gustavianere havde det sværere. Forhadte politikere og embedsmænd sendtes ud på landet eller til udlandet som diplomater til fjerne egne - eller kom endnu mere galt af sted -, og for at overvåge mistænkte individer, dannedes et raffineret efterretningsvæsen. Og måske vigtigst af alt: trykkefriheden indskrænkedes.

Dette var ganske vist sket allerede under Gustaf IIIs regeringstid, og Reuterholm var debuteret med at proklamere en omfattende trykkefrihed, noget som skiftevis er blevet opfattet som et tegn på et frihedselskende sindelag, og som et forvirret tegn på hans manglende evne til at tænke klart. Hvordan det end var: Først og fremmest af skræk for at begivenhederne i Frankrig skulle brede sig til Sverige, genindførte Reuterholm snart en censur som indimellem kom til udtryk på grotesk vis, både under hertug Carl og selv efter at Gustaf IV Adolf var blevet myndig.

Med tanke på hvor denne artikel trykkes, kan det vel have en vis interesse, at 


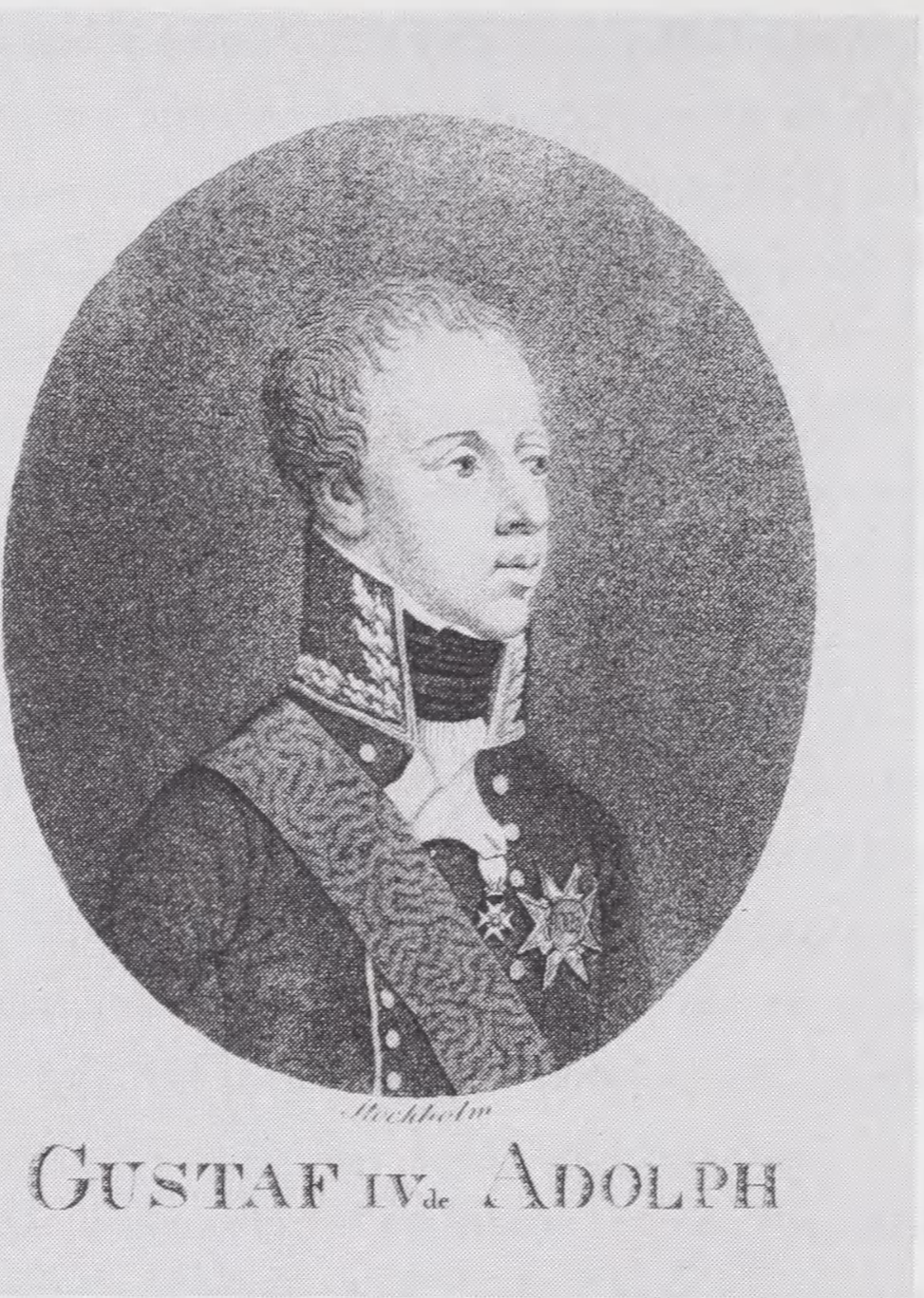

Gustav III's søn, Gustav IV Adolf. Svensk konge 17921809, død 1837.

Gustav IV Adolf arvede tronen som 14-årig og fik sin farbror, hertug Karl, som formynder. Samme hertug Karl overtog regeringen efter revolutionen i 1809, hvor Gustav IV Adolf måtte forlade Sverige.

man i 1803 udfærdigede et forbud mod at indføre danske bøger og tidsskrifter i Sverige, samtidig med at salget af allerede importeret dansk litteratur blev stoppet. Danske forfattere måtte heller ikke udgives i Sverige, hverken på originalsproget eller i oversættelse. Anledningen var at et par danskere havde udtrykt sig sårende om kongens måde at lede sin regering. ${ }^{30}$ At påstå, at sådan noget "besværede de dansk-svenske forbindelser på kulturområdet”, som Louise Vinge lakonisk konstaterer i en litteraturhistorie, ${ }^{31}$ er i hvert fald ikke nogen overdrivelse.

Eftersom man i Danmark anså det for nytteløst at indføre danske skrifter i Sverige på sædvanlig vis, valgte man i et tilfælde en usædvanlig fragtvej. Et antal eksemplarer af et smædeskrift om Gustaf IV Adolf, som blev trykt i København, fæstnedes til luftballoner, som man ved den rette vindretning lod drive ind over den skånske kyst. Dér stod imidlertid et antal politibetjente parat og de indsamlede de dalende balloner, hvorfor et yderst lille antal af skriftet nåede læserne. ${ }^{32}$

At også et musikstykke kan være en torn i øjet på magthaverne, ved vi jo fra andre forhold. At den revolutionære tekst til Marseillaisen blev genstand for Reuter- 
holms og senere Gustaf IV Adolfs interesse kan man nok forstå, men at også musikken skulle blive genstand for forfølgelse skal jeg vise med et eksempel.

Da kongen skulle krones år 1800, havde Det Akademiske Kapel ved Uppsala Universitet fået til opgave at give en koncert til hans ære. Docenten G.A. Silfverstolpe lokkede da dirigenten til at spille et stykke af komponisten F. Metzger, "Bataille de Fleurus". Hvad Metzger ikke vidste, var at musikken til Marseillaisen indgik i stykket, og da rektor magnificus efter en gennemgang fandt ud af dette, påbød han i stedet en Haydn-symfoni. Musikerne vægrede sig alle på nær tre, og musikken blev derfor spillet med en meget lille besætning. Bagefter blev Silfverstolpe frataget sit docentur, blev forvist fra universitetet, og pålagdes forinden at gøre afbigt hos rektor. ${ }^{33}$

Naturligvis blev også teatret udsat for prøvelser, og efter Gustaf IV Adolfs tronbestigelse var disse ikke bare af politisk art. I en opera havde en prinsesse forelsket sig $\mathrm{i}$ en yngling og som frugten af dette var hun nedkommet med et barn. Det oprørte kongen at en ugift pige ikke blot fik et barn, men også at moderen oven i købet var kongeligt blod. Derfor afskedigede han ikke blot prinsessen, men også hele den franske skuespillertrup, hvori hun indgik. ${ }^{34}$

For et andet fransk teaterstykke gik det ikke bedre. I handlingen indgik en oplæsning af en roman, hvori en prinsesse blev taget til fange af røvere, bundet og tiltalt på mindre høvisk vis, samtidig med at hendes tøj kommer i uorden. Gustaf Adolf blev rasende og udfærdigede et kongeligt brev den 13. maj 1805, hvori han afskedigede også denne trup.

I begge disse tilfælde indgik den moralske indignation tilsyneladende en forening med den politiske mistænksomhed, da Gustaf Adolf så ethvert angreb på en kongelig person som et kamoufleret angreb på sin egen person.

I det hele taget skete der på teatret i denne periode en tydelig kursændring fra det franske til det tyske. Af moralske grunde måske, men først og fremmest fordi Frankrig som følge af revolutionen og begivenhederne derefter var om ikke et lukket, så i hvert fald et farligt land. Noget som dog medførte det positive, at det svenske teaterpublikum lærte tyske dramatikere nærmere at kende, som f.eks. August von Kotzebue og hans satirer og familiedramaer.

Mange intellektuelle henførtes $\mathrm{i}$ begyndelsen, når de så friheds- og oplysningsideerne tage form under den franske revolution, mens magthaverne skræmtes af den, i særdeleshed da man begyndte at kappe hovedet af folk i Paris. Censuren 
havde forståeligt nok en vis effekt. Hvad man ikke kom til livs, var selskabsvisen, som havde fået en utrolig popularitet - gennem Bellman naturligvis, men også gennem andre som anvendte genren for at udtrykke tanker i forklædt form. Mest kendt blev den såkaldte "Sansculottevise". De franske radikale gik uden knæbukser, culottes, og da Hans Hierta lovsang bukseløsheden i en vise, var det en skjult hyldest til de revolutionære. 35

Den vigtigste efterfølger til Bellman må siges at være Frans Mikael Franzén. Jeg har selv en svaghed overfor musikaliteten og det håndværksmæssige $i$ hans poesi, og er ikke enig med Daniel Andrex når han siger, at af "Franzéns egen lyrik er der næppe mere end nogle spredte linier der endnu har deres livskraft i behold" . ${ }^{6}$ Bedre synes jeg om Louise Vinges beskrivelse af ham som et af "de strenge års lys", sammen med Johan Olof Wallin. ${ }^{37}$ At Franzén aktivt bidrager til den svenske verdensrekord i antallet af biskopper (han var biskop i Härnösand) som skrev drikkeviser, påvirker naturligvis ikke min dømmekraft.

I årene før Gustaf IV Adolfs detronisering var Sverige isoleret fra kontakter med udlandet; udenlandsk litteratur - ikke bare den danske - betragtedes med mistro ligesom udlændinge som kom til Sverige; de formodedes at være spioner. At rejse ud var heller ikke det letteste. Desto mere forfriskende er det at gøre sig bekendt med Franzéns rejsedagbog fra årene 1795-96.

Franzén brændte af iver for at se hvordan revolutionen forandrede situationen til frihedens fordel, og Paris blev derfor et vigtigt rejsemål. Da han vandrede omkring i det han forestillede sig som frihed på jord, blev han imidlertid skuffet. I menneskenes ansigter så han resignation i stedet for entusiasme. Efter feberen var der indtruffet en mathed, og det fik ham til at revidere sin politiske opfattelse.

Derimod passede det borgerlige England ham bedre. Op imod det franske teater, som han fandt opstyltet, satte han nu det engelske med Shakespeare, som han beundrede uden forbehold, ligesom han foretrak de engelske parker frem for de franske. Tilsyneladende en interesse for den æstetiske frihed i før-romantikkens tegn, i stedet for en kølnet interesse for den politiske frihed.

Men også Franzéns korte besøg i København kan måske være af interesse. På Det kongelige Bibliotek falder han i svime over de 200.000 bind, mens han bestyrtes da han betragter rytterstatuen på Kongens Nytorv. En kvinde, som iagttager hans interesse for statuen, forklarer ham nemlig, at det er den svenske konge som hesten 
Frans Mikael Franzén, 17721847 , Bellmans vigtigste efterfølger. 1834 biskop i Hernösand. Hans produktion omfatter poesi, drikkeviser og salmer.

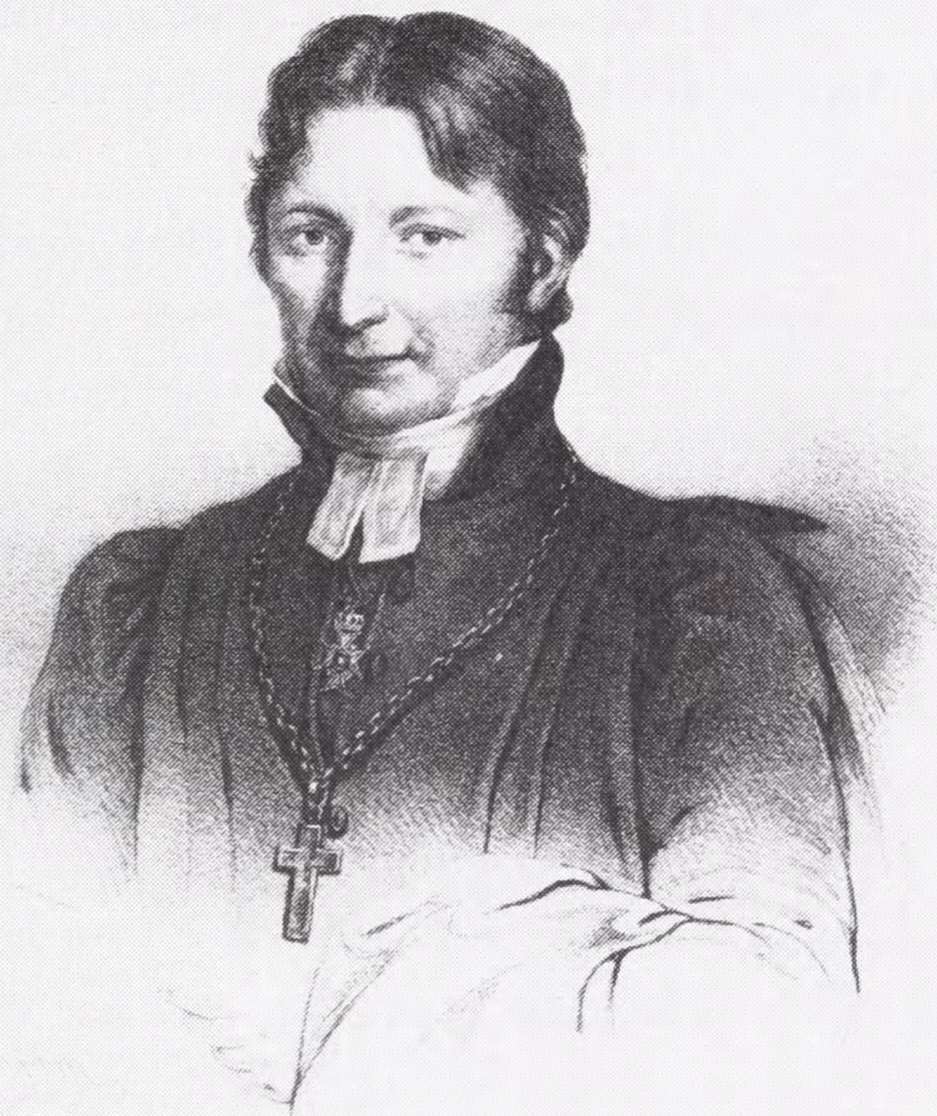

tramper under fode. Efterhånden finder Franzén dog ud af, at det aldeles ikke er den svenske konge, men den allegoriske figur Misundelsen, der maltrakteres. ${ }^{38}$

Foruden Franzéns digt "Menneskets åsyn” fra 1793 er Kellgrens "Den nye skabelse" - som udkom allerede mens Gustaf III levede - den fornemste forløber for romantikken i svensk litteratur. I lighed med Bellman og Franzén skrev Kellgren også viser om Venus og Bacchus, oven i købet en gang en vise som beskriver hvordan man lokker piger ved hjælp af alkohol: “Thi når Bacchus for os strider / skønhed sig snart overgiver". 39

Da Gustaf III døde, var Kellgren imidlertid en døende mand, som skulle komme til at gøre Bellman selskab gennem mørkets port i 1795. Så længe Gustaf III levede, tilhørte han af og til dennes beundrere, af og til var han stærkt kritisk, men hans hyldester til kongen står ikke tilbage for Bellmans hvad sleskhed angår: "Glæd dig, Stockholm, glæd dig og syng / Han er her! Hvor hjertet røres / Når det salige udråb 'høres: / GUSTAF! GUSTAF! Han er her!”, udråber Kellgren, da kongen vender tilbage fra sit ophold ved et kurbad. 40 Vigtigt for netop Kellgrens digtning var det, 
at censuren lettede i en kort periode efter kongens død, og hans oplysningsdigt "Lysets fjender" blev et af de mest betydningsfulde i den strøm af publikationer, som han lod udkomme inden tommelskruerne strammede til og censuren skærpedes. 41

Leopold hed altså den mand, som skrev librettoen til Gustaf III's begravelse. Det var også til ham, som Bellman dedicerede et afsnit af sit teaterstykke Fiskerhytten ${ }^{42}$ og hele den smukke epistel 82, "Hvil ved denne kilde". 43 Blandt dem, som har hyldet Gustaf III, fører Leopold an hvad underdanighed angår. Hvad skal man f.eks. mene om denne passus: "Ingen anden end Gud kan som Deres Majestæt kunsten at se alt, tænke på alt og udrette alt på en gang." Ja, han går endog et skridt videre og siger, at man kan have "vanskeligheder ved Guds væsen", dvs. man kan tvivle på Guds eksistens, mens Gustaf beviseligt er til!44

Leopold var den fødte hofmand, eller opportunist om man vil, den glatteste af de glatte, og han synes på mirakuløs vis at have undgået de nye magthaveres lange fingre uden fuldstændigt at sælge sin sjæl. Han var den vigtigste medarbejder på Extra Posten, en avis som udkom 1792-95. I denne tournerede Leopold et digt "Til Hans Kongelige Højhed Hertugen Regenten”, hvori han berømmede dennes nye overflodsforordning. Først hyldede han Carl som krigsherre og fredsfyrste - alene kombinationen kan jo give anledning til mistanke - og endelig priste han hertugen for at denne nu havde fuldbragt sin fortegnelse over præstationer med det eneste som manglede: at befri landet for unødig luksus. ${ }^{45}$ Mærkeligt nok blev det alligevel hofmanden Leopold, som blev årsag til avisens endeligt. En artikel af ham opfattedes nemlig som ærekrænkende - ikke over for magthaverne, men derimod over for Martin Luther - og avisen lukkede.

En, der virkede som forfatter under hele denne periode, var Anna Maria Lenngren, og måske er det mærkeligt, at hendes bidende satirer ikke vakte større politisk opmærksomhed end de gjorde, eksempelvis den åbenbare hyldest til frihed, lighed og broderskab som findes i "Drengene" (1797) eller "Vauxhallen" (1796).

Men hun befandt sig på grænsen. I 1798 skærpede Gustaf IV Adolf censuren, og det blev helt klart, at eksempelvis sådanne angreb på adelen, som fru Lenngren tidligere var kommet med, nu ikke længere var ønskværdige. Derfor holdt hun op med at skrive noget politisk kontroversielt i Stockholms-Posten.

Et, digt som bestandigt synes at lokke til nye diskussioner, er fru Lenngrens 
Carl Mikael Bellman, 1740-

1795.

Som digter stod han på overgangen mellem 'frihedstiden' og den gustavianske tid.

Ved kong Gustav IIIs gunst opnåede han i 1776 en bestilling som sekretær ved tallotteriet, en slags "digterløn".

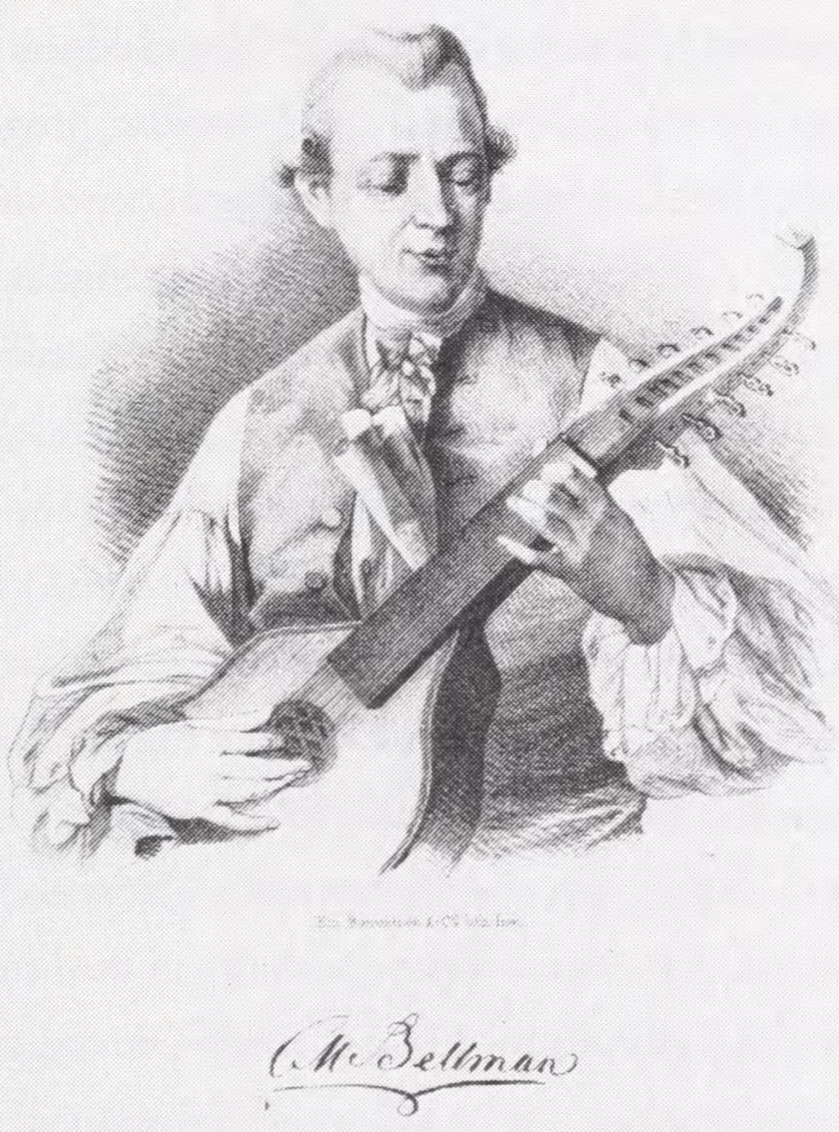

"Nogle ord til min k. datter - ifald jeg havde nogen" fra 1798, og en læser som mener at man hidtil har misforstået dette digt er Agneta Pleijel. Hun forklarer, at den skrappe politiske situation mod slutningen af 1790erne udgør en nødvendig baggrund for forståelsen af digtet: netop når Stockholms-Posten rammes af politisk bagslag, afsløres fru Lenngrens identitet, og hendes frihed som digter er dermed stærkt beskåret. Så sætter hun sig ned og skriver digtet til sin k. datter.

Ifølge Pleijel gør digtet sit bedste for at fremstille kvinden som fuldstændig ufarlig for offentligheden, hvilket fru Lenngren ikke selv har været, men tvinges til at blive. “[hvor] mange undertrykte kvinder anvender ikke i dag præcis samme argument $\mathrm{i}$ den hensigt, mutatis mutandis, at tilkæmpe sig en vis placering i toppen, hvor tilfældigt det end kan være?” spørger Agneta Pleijel retorisk. Det er derfor fru Lenngren i digtet kan skrive: "Når en kvinde sig samvittighedsfuldt ter / staters styrelse at ransage /Ved Gud, så forekommer det mig at jeg ser / en skygge af skæg om hendes hage." 46

Anna Maria Lenngren synes ikke at have haft nogen forståelse for den nye følsomhed, der fornemmedes i det europæiske kulturliv i slutningen af 1700-tallet, 
den såkaldte før-romantik, som påvirkede folk som Bellman, Kellgren og Franzén. Dens største lyriker var imidlertid Bengt Lidner. Hvis man "samkører" Bellmans og Lidners navne - med en term lånt fra datasprog - så finder man interessante ting. Lidner oplevede blot ét af de strenge år, men det var besværligt nok og han døde ludfattig. Tidligere havde han med sine sange samlet penge sammen til trængende venner, men nu da det blev den Lidnerske families egen tur til at sulte og fryse, var Bellman næsten den eneste der kom dem til hjælp: "Vis ømhed, vis nåde / Mod Poeten Lidners Enke" skrev han i et opråb, som indsamlede 50 rigsdaler. ${ }^{47}$ Altså et eksempel på Bellmans generøsitet. Som en lille pige skrev i en stil: "Selvom Bellman selv havde flere børn, tøvede han aldrig med at hjælpe dem der manglede." Eller mere seriøst udtrykt af Paul Britten Austin: "Et mere godhjertet menneske end Bellman har næppe eksisteret." 48

Den anden store før-romantiker, Thomas Thorild, behøvede Bellman aldrig hjælpe, eftersom han overlevede Bellman med tretten år og desuden aldrig prøvede at leve i fattigdom som Lidner. Nogle enkelte gange synes Bellman og Thorild at have mødtes, den ene med dyb indlevelse i de fordømtes vilkår, den anden betragtende mennesket med filosofisk ophøjethed. ${ }^{49}$

Man har spekuleret på, om Thorild skulle have tilhørt de sammensvorne ved mordet på Gustaf III, visse indicier peger i den retning, men Stellan Arvidson har i sin store Thorild-monografi på en overvisende måde helt befriet skjalden for den mistanke. ${ }^{50}$ Derimod er det sandt, at han var den svenske intellektuelle som mest henført hyldede den franske revolution, i begyndelsen også dens voldsgerninger: De gamle ledere skulle halshugges, og købstæderne, "disse reder for galskaben", brændes. Efterhånden bliver Thorild imidlertid skræmt af revolutionen og med sin epileptiske stil (udtrykket er Kellgrens), kalder han Robespierre en krokodille og franskmændene for tigeraber. ${ }^{51}$

Thorild var faktisk årsag til ,at den korte tid med trykkefrihed sluttede i 1792. Under henvisning til at revolutionen ville stå for døren, hvis intet blev gjort, lod hertugen sig overbevise om, at dels burde friheden indskrænkes, dels at forfatteren til en formodet samfundstruende pamflet burde fængsles. Dette skete også, og forfatteren var netop Thomas Thorild. Anklageren krævede at Thorild skulle dømmes til døden, mens han selv - naturligvis - ville frikendes. Resultatet blev et kompromis: fire års landflygtighed. 52 
Processen mod Thorild og indskrænkningen i trykkefriheden skete ikke ubemærket. I Stockholm fulgtes Thorilds vogn på vejen til hofretten af en folkemasse som råbte: "Leve Thorild og friheden!”, i Uppsala iførte nogle studenter sig sørgeflorskokarder, og man iscenesatte en begravelse hvor man jordfæstede et eksemplar af den nyligt ved døden afgåede trykkefrihedsforordning. 53

Med sin landflygtighed gør Thorild en dramatisk sorti ud af svensk trykkefrihedshistorie. Dog fik han det ikke så forfærdeligt svært: Han blev bibliotekar, senere også professor, i det daværende svenske Greifswald.

De strenge år sluttede altså med Gustaf IV Adolfs detronisering. Som Strindberg har påpeget, er det ikke helt ufarligt at være svensk konge, selv om risikoen er mindre end for eksempelvis præsidenter i USA: Erik XIV blev formentlig myrdet, at Karl XII faldt for en fjendes kugle er ikke 100\% sikkert, Gustaf III døde med Ankerströms skrot i kroppen og hans efterfølger havnede i fængsel og siden i livsvarig landflygtighed.

Til forskel fra kunstnernes beskytter Gustaf III, interesserede Gustaf Adolf sig ikke for æstetik; i stedet for at hjælpe skadede han sagen. Som modvægt tilskriver historikerne ham nu en del vellykkede indenrigs reformer samt en vis sans for økonomiske realiteter. Det var heller ikke på grund af manglende æstetiske følelser at kongen blev sat af rigets trone, men af politiske årsager: Nederlaget i den finske krig 1808-09 vakte voldsom harme blandt Sveriges officerer og yngre embedsmænd, og kongen blev dadlet for tabene.

Litterært set er den sengustavianske epoke den magreste siden Karl XIIs tid, og det gælder både tiden før og efter Gustaf Adolfs myndighedsdag i 1796. Alligevel er det interessant at studere åndskulturen i denne periode, selv om sandheden $\mathrm{i}$ hvad en af Gustaf IIIs fjender siges at have sagt efter mordet er åbenbar den dag i dag: Livet blev betydeligt mere kedsommeligt da han døde!

Noter

1 Lars Forssell, Galenpannan. Skådespel $i$ àtta bilder (1964) i samlingen Teater II (Lund, 1977), s. 76.

2 Carl Michael Bellmans Skrifter. Standardupplaga udgivet af Bellmanssällskapet, II, Fredmans sainger (Stockholm, 1932), s. 153.

3 Standardupplagan, VII, Dikter till Gustaf III och konungahuset (Stockholm, 1938), s. 14.
4 “Öfver den 22 Augusti 1772", Standardupplagan, VII, s. 17.

5 Haren och Vräken. Skådespel (Lund), s. 84

6 "Arrêtez lui mais ne lui faites pas mal", ifølge Gustaf Löwenhielms memoirer. Her gengivet efter Den svenska historien, X, Gustaf III, en upplyst envaildshärskare, hovedred. Jan Cornell (1968), (Stockholm,1979), s. 215. 
7 Således tror øjenvidnet Löwenhielm, ibid.

8 Jvf Anna Johnson, "SorgMusiken wid Högstsal. Konungens Begrafning. En opera om den tredje Gustaf", Artes 1987:1, s.66.

9 Ikke udgivet, men citeret i kommentaren til Standardupplagan, VII, s. 156.

10 "Den 30 Mars 1793 vid Konung Gustaf IIIs död", Standardupplagan, VII, s. 156.

11 "Konungens DÖD och MINNE, på KlagoDagen den 6 Junii 1792. Uppläst uti AugustiOrden af C.M.B.", Standardupplagan, VII, s. 157-167. Citatet fra s. 167.

12 Anekdoten gengives af Sven Delblanc i Den Svenska Litteraturen, II, Upplysning och romantik, red. Lars Lönnroth \& Sven Delblanc (Stockholm, 1988), s. $214 \mathrm{f}$.

13 En kuriositet, lad gå. Jeg har fundet den i Myggans Nöjeslexikon. Ett uppslagsverk om underhållning, IV, hovedred. Uno Myggan Ericson (Höganäs, 1990), s. 123.

14 Citeret efter Johnson, s. 68.

15 Svenskt 1700-tal i musiken. Musika Svecia. Svensk musikhistoria på fonogram. MSCD 903, 1993.

16 Jvf Johnson, s. 70.

17 Bengt Åhlén, Ord mot ordningen. Farliga skrifter, bokbål och kättarprocesser i svensk censurhistoria (Stockholm, 1986), s. 145.

18 Ibid.

19 Paul Britten Austin, The life and songs of Carl Michael Bellman, Genius of the Swedish Rococo. Overs. Gun \& Nils A. Bengtsson, Carl Michael Bellman. Hans liv, hans miljö, hans verk (1970), andet svenske oplag (Stockholm, 1979), s. 181.

20 Ordene er Bernhard Elis Malmströms og citatet er taget fra Åhlén, s. 146.

21 Åhlén, s. 146.

22 Per Daniel Amadeus Atterbom, Samlade Skrifter i obunden stil. Tredje delen. VI:I. Svenska siare och skalder eller grunddragen af svenska vitterhetens häfder intill och med Gustaf III:s tidehvarf, andra upplagan (Örebro, 1863), s. 27. Jvf Åhlén, s. 146

23 Austin, s. 204.

24 Atterbom, s. 28. Jvf Åhlén, s. 146.

25 "Upläst i Augusti Orden högtifd-dagen d. 19 Aug. 1794 af Ordens Taleman CMB", Standardupplagan, VII, s. $182 \mathrm{f}$. De to kronede helte er Gustaf II Adolf og Gustaf III.
Jf. kommentaren, s. $180 \mathrm{ff}$.

26 Standardupplagan, bind VI, Dramatiska arbeten (Stockholm, 1936), s. 197-271. Jf. kommentaren s. $180 \mathrm{f}$.

27 "Kongl. Slottet den 8 Maji 1794. 1. arket. Lefverne af C M Bellman tillhörig Doctor Blad", står der i Standardupplagan som overskrift til det første afsnit. Bind XII. Dikter till enskilda, V, 1794 jämte Tillägg. Dikter till konungahuset. Tillägg (Stockholm, 1974), s. 16. Hele beskrivelsen findes s. 16-23.

28 Jf. Nils Afzelius, "Bellman och Wallenberg", Ny illustrerad svensk litteraturhistoria. Andra delen. Karolinska tiden. Frihetstiden. Gustavianska tiden (Stockholm, 1956), s. 289.

29 Efter Alma Söderhjelms bog om Sverige og den franske revolution i Olle Holmberg, Leopold och Reuterholmska tiden 1792-1796 (Stockholm, 1957), s. 35.

30 Åhlén, s. 181 f.

31 Louise Vinge, "Från järnår till romantisk skördetid - en periodöversikt", Den svenska litteraturen, s. 187.

32 Åhlén, s. 182 f.

33 Ibid., s. $163 f$.

34 Ibid., s. $167 f$.

35 Lars Lönroth, "Revolutionens röst: Sansculotte-visan", Den svenska litteraturen, s. 211.

36 "Den romantiska tidsåldern i svensk litteratur", Den svanska historien, XI, Finland forloras. Karl Johan och freden, hovedred. Gunvor Grenholm (1967), (Stockholm, 1985), s. 120.

37 Louise Vinge "Järnårens ljus - Franzén och Wallin", Den svenska litteraturen, s. 205.

38 Franz Michael Franzén, Resedagbok 1795-96. I udvalg og med indledning af Anders Hernmarck (Stockholm, 1977), s. $31 \mathrm{f}$.

39 Citeret efter Tage Danielsson, "Till Johan Henrik Kellgren”, Författarnas litteraturhistoria. Den forsta boken, red. Lars Ardelius \& Gunnar Rydström (Stockholm, 1978), s. 183.

40 Citeret efter Danielsson, s. 185.

41 Alf Kjellén har skrevet om dette i Samlaren. Tidskrift for svensk litteraturhistorisk forskning 1941 (Uppsala, 1942), i essayet "Kellgrens Ljusets fiender och den samtida politiska situationen".

42 "Fiskarstugan. Pastoral på Fru Palmstedts 
fodelse-dag den 18 januarii 1792", Standardupplagan, VI, s. 190.

43 "N:o 82. Fredmans Epistel, Eller Oförmodade Afsked, förkunnadt vid Ulla Winblads Frukost en sommar-morgon i det gröna”. Standardupplagan, band 1. Fredmans epistlar (Stockholm, 1927), s. $271 \mathrm{ff}$.

44 Austin, s. 180f.

45 J. Viktor Johansson, Extra Posten 1792-1795. Studier i 1790-talets svenska press- och litteraturhistoria. Förra delen: Tidningens historia, dess politiska och litterära innehall (Göteborg, 1936), s. 167f.

46 Agneta Pleijel, "Den kvinnliga författaren och offentligheten. Om Anna Maria Lenngren”, Författarnas litteraturhistoria, s. 210-219. Lenngren citeret efter Carl Ivar Ståhle \& E.N. Tigerstedt, Sveriges litteratur, IV, Gustaviansk litteratur, udg. A.E. Sjöding (Stockholm, 1963), s. 163.
47 Standardupplagan, XI, Dikter till enskilda. IV. 1790-1793 (Stockholm, 1964), s. 190, "Om begravnings-hjelp åt Lidner". Jvf. Austin, s. 171, Huldén, s. 140 samt Bellman sedd och hörd. Porträtt, dokument och vittnesbörd sammen-stillet af Leif Kretz, Sten Åke Nilsson \& Torkel Stålmarck (Stockholm, 1994), s. 138.

48 Austin, s. 171

49 Jvf. Sivar Arnér, "Thomas Thorild", Författarnas litteraturhistoria, s. 195.

50 Stellan Arvidson, Harmens diktare. Thorild, II (Stockholm, 1993), s. 556-573.

51 Arnér, s. $190 \mathrm{ff}$.

52 Se Arvidson, s. 605-650 og Åhlén, s. $152 f$.

53 Anders Grape, "Tidsrörelser inom studentvärlden i Uppsala 1792-1793. Tryckfrihetens begravning och studentkonventen", Samlaren 1923 (Uppsala, 1924), s. 187-193. 